\title{
Transmigration Regional Multicultural Society, Analysis of Reading Literacy in Sumbawa Districts
}

\author{
Syamsul Bahri* \\ Doctoral student at the Indonesian University of Education and \\ Lecture at University of Samawa \\ Sumbawa, Indonesia \\ syamsulbahrisn@upi.edu \\ S Syihabuddin \\ Indonesia University of Education (UPI) \\ Bandung, Indonesia \\ syihabuddin@upi.edu
}

\author{
D Damayanti \\ Indonesia University of Education (UPI) \\ Bnadung, Indonesia \\ vismaia@upi.edu \\ Yeti Mulyati \\ Indonesia University of Education (UPI) \\ Bandung, Indonesia \\ yetimulyati@upi.edu
}

\begin{abstract}
The transmigration community is a multicultural society; this is because those who occupy the territory come from various regions. The variety of multicultural societies can influence different understanding and attitudes under students in the school environment. Different students sometimes trigger disputes and lead to fights. Based on the points stated, the teacher needs to provide a stimulus to increase understanding of these cultural differences by increasing reading literacy related to the culture of each student. The obstacle that arises then is do students have the ability to read literacy sufficient to understand the literature. The purpose of this study is to describe the ability to read the understanding of students in junior high schools in transmigration areas in the Labangka subdistrict, Sumbawa Regency. The theory used to capture the ability of students to read is the principles of reading and the factors that influence reading ability the research methodology used is qualitative with the research instruments using observation questionnaires and interviews with teachers and students. Research findings, interviews with teachers based on indicators (1) Accessing and retrieving information from texts, (2) Integrating and interpreting what is read, (3) Reflecting and evaluating text and connecting with reading experiences is $53 \%$ of students are unable to access, integrate and reflect the text, $25 \%$ of students are less able to access, integrate and reflect the text and $5 \%$ of students are able to access, integrate and reflect the text. The next result of observations made to students is related to how the teacher's process increases the ability to read the students' literacy by observing students, namely, the teacher in teaching monotone, the teaching material media are still inadequate. The conclusion of the transmigration community in Labangka Subdistrict, Sumbawa Regency, has a low reading ability caused by monotonous teachers with the learning models used, teaching materials and inadequate media.
\end{abstract}

Keywords: transmigration areas, multiculturalism, literacy, reading ability

\section{I.INTRODUCTION}

Indonesian society is an advanced society and has a variety of ethnicities, religions and races Cultural capital so as to form a society that has a different culture or a multicultural society that is characteristic and at the same time that the power makes the difference as a blessing of the nation [1]. Axis areas are also regions that have various cultures that is transmitted by transmigrants Mc Andrew \&
Rahardjo's research shows that transmigration programs and migration of people from one area to another have resulted in conflicts between ethnic migrants and indigenous people, the problem always relates to land ownership rights that are increasingly scarce, the balance ecology areas are increasingly critical, and a strong cultural clash between indigenous people and migrants [2].

The results of these studies indicate cultural factors become an important part that needs to be considered in the process of planning and controlling development [2]. Phenomena that occur related to cultural differences, will have a significant impact on students. Therefore, it is necessary to make innovations to heal the conflict. At this time, what the Sumbawa District government is doing is a literacy movement in accordance with 21 st century claims made in schools and reinforced by the 2017 governor's regulation as stated by Husni Djibril in a local newspaper [3]. However, this has not been done optimally, the obstacles that occur are the low literacy ability of students, the awareness of the importance of literacy, reading to provide the impact of knowledge that can help in overcoming disputes contained in these cultural differences. From these ideas, it is necessary to study the level of literacy knowledge of students in transmigration areas in Sumbawa Regency.

Reading literacy based on the Program for International Students Assessment (PISA) has assessment indicators, namely, firstly the type of text used, secondly aspects of student understanding and thirdly aspects of social situations. This research focuses on aspects of student understanding with indicators of accessing and retrieving information from text, integrating and interpreting what is read, reflecting and evaluating text and connecting with reading experiences [4].

\section{II.MET HODS}

The methodology used in this research is descriptive qualitative with a case study approach that occurs in one object or single, by understanding concepts that occur in research objects such as behavior, actions and motivation as a whole from the data to be analyzed by observation an

interviews with participating students and teachers. Primary data were collected by surveying the first object, namely from the teacher and students at the research 
location conducted at the First, Middle School (SMP) 1 Labangka District, Sumbawa Regency. Secondary data obtained from the documentation and literature collected from observations related to supporting documents of the research object. The sample locations used were taken according to the researchers to be representative and relevant to the research conducted.

This is due to several considerations, namely, the object of research has a diverse multicultural consisting of Sumbawa, Sasak, Bima, Bali, Javanese and Bugis. Taking a research sample using random sampling. The number of students used as research samples 20 students were randomly selected from the total population of the three classes the number of students in total 60 students The research data collection technique used was observed using a questionnaire and the results of interviews which were subsequently analyzed. Validity is related to reading literacy indicators by giving coding for students with numbers 01, 02.03 and so on and further research indicators consist of 3 aspects, namely, (a) Accessing and retrieving information from text, (b) Integrating and interpreting what is read, (c) Reflect and evaluate text and relate it to the reading experience. Instrument development and interviews are validated by expert, experts and triangulation stages are carried out [5]. Analysis of research data was done by analyzing artifacts and data from observations and interviews.

\section{RESULTS AND DISCUSSION}

The findings of the research are related to the ability to read literacy, which focuses on aspects of student understanding with indicators of accessing and retrieving information from text, integrating and interpreting what is read, reflecting and evaluating text and connecting experiences with reading. Rating of three indicators with each indicator has a descriptive rating to determine their respective variables.

Descriptors of the first indicator, i.e. Students can access and retrieve information from what is read given a value of 3 , less able to access and retrieve information from what is read given a value of 2 , cannot access and retrieve information from what is read given a value of 1 . Furthermore, it can integrate and interpret what is read given a value of 3 , less able to integrate and interpret what is read given a value of 2, cannot integrate and interpret what is read given a value of 1 , and further indicators can link with the reading experience given a value of 3 , less able to connect reading experience is given value, and cannot relate to reading experience given value. Based on the indicators of the three descriptors used as a reference for analyzing reading literacy abilities, it can be seen in table 1 that is as follows.

TABLE I. FINDINGS OF RESEARCH FINDINGS ON LITERACY, READING SKILLS

\begin{tabular}{|c|c|c|c|}
\hline \multirow{2}{*}{ Student Data Coding } & \multicolumn{3}{|c|}{ Rating Indicator } \\
\cline { 2 - 4 } & A & B & C \\
\hline 01 & 2 & 1 & 1 \\
\hline 02 & 1 & 1 & 1 \\
\hline 03 & 2 & 1 & 1 \\
\hline 04 & 3 & 2 & 2 \\
\hline 05 & 2 & 1 & 1 \\
\hline
\end{tabular}

\begin{tabular}{|c|c|c|c|}
\hline \multirow{2}{*}{ Student Data Coding } & \multicolumn{4}{|c|}{ Rating Indicator } \\
\cline { 2 - 4 } & A & B & C \\
\hline 06 & 2 & 2 & 1 \\
\hline 07 & 2 & 2 & 1 \\
\hline 08 & 2 & 2 & 2 \\
\hline 09 & 2 & 3 & 1 \\
\hline 10 & 2 & 2 & 2 \\
\hline 11 & 1 & 1 & 1 \\
\hline 12 & 1 & 1 & 1 \\
\hline 13 & 2 & 1 & 1 \\
\hline 14 & 2 & 1 & 2 \\
\hline 15 & 1 & 1 & 1 \\
\hline 16 & 3 & 1 & 2 \\
\hline 17 & 2 & 2 & 2 \\
\hline 18 & 1 & 1 & 1 \\
\hline 19 & 1 & 1 & 1 \\
\hline 20 & 2 & 1 & 2 \\
\hline
\end{tabular}

Based on Table I: Findings from the research, interviews with teachers based on indicators (a) Accessing and retrieving information from the text, (b) Integrating and interpreting what is read, (c) Reflecting and evaluating text and linking to the reading experience that there are $53 \%$ students not able to access, integrate and reflect the text, $25 \%$ of students are less able to access, integrate and reflect the text and 5\% of students are able to access, integrate and reflect the text. In addition to the findings related to students 'literacy, reading abilities, observations were also made on students, which included how the teacher improved students' literacy reading skills. The results of observations of learning models conducted by teachers are still monotonous, supporting media used by teachers are still limited and the use of literature does not reflect multiculturalism.

Based on the phenomenon of the limitations of students and teachers to improve literacy skills correlate with frequent conflicts in the transmigration area of Sumbawa Regency. Researcher's assumptions based on the limited literacy ability of reading have an impact on the local community disputes occur due to the lack of cultural understanding between students who have different cultures. Students who have different cultures will influence behavior. As stated by Tajfel Social groups have interactions among their members which involve the process of social categorization, namely the rules in the social environment regarding the grouping of people in a code of behavior that makes sense for individuals. The social category will then determine the behavior patterns of members of certain social groups which will ultimately shape the social identity of the group [1].

Problems that exist in a particular community or group will respect each other, if each group or individual is able to understand the cultural differences that are owned. Therefore, there needs to be innovations that can be developed, one of which is through increasing literacy, reading skills as a vehicle for understanding different cultures. The implications of the findings that have been presented can be carried out in-depth studies related to the limitations of students and teachers to improve literacy skills that provide a positive distribution of advocates of social conflict that occurs in areas of migration that have diverse cultural. 


\section{CONCLUSIONS}

Overcoming a cultural conflict that occurs within a group of people, can be done by understanding the differences of each culture by reading the literature related to the cultural concepts contained in these differences. A fundamental step can be taken earlier in the school environment by increasing literacy skills among students and teachers. Based on research conducted in the transmigration area of Sumbawa Regency, related to students' literacy is relatively low. The low literacy ability of students is also caused by teachers who still do not use innovative learning models and inadequate media. Therefore, it is necessary to do innovations that can improve reading skills oriented to cultural diversity. With the increased ability of students' literacy, reading ability will correlate positively to the complications that occur related to the culture contained in groups or individual communities.

\section{ACKNOWLEDGMENTS}

The research carried out can be completed, not apart from assistance from the leadership and Indonesian language teachers of State Middle School Labangka 1 Sumbawa District who have provided a distribution related to the data needed in the research

\section{REFERENCES}

[1] J. Najwan, "Konflik Antar Budaya dan Antar Etnis di Indonesia Serta Alternatif Penyelesaiannya," J. Huk. ius quia iustum, vol. 16, 2009.

[2] E. MacAndrews, Colin \& Rahardjo, "Pemukiman di Asia Tenggara dan Transmigrasi di Indonesia," Suatu Popul., vol. 19, no. 1, 1982.

[3] "Sumbawa dan Lombok Utara Serah Terima Program Gema Literasi - Samawa Rea." https://www.samawarea.com/2018/07/24/sumbawa-danlombok-utara-serah-terima-program-gema-literasi/ (accessed May 11, 2021).

[4] OECD, PISA 2012 Assessment and Analytical Framework: Mathematics, reading, science, problem solving and financial literacy. 2013.

[5] I. Gunawan, "Metode penelitian kualitatif," Jakarta Bumi Aksara, vol. 143, 2013 